\title{
Estimation of surface runoff using NRCS curve number in some areas in northwest coast, Egypt
}

\author{
Mohamed E.S ${ }^{1}$. Abdellatif M.A ${ }^{1}$. Sameh Kotb Abd-Elmabod ${ }^{2}$, Khalil M.M.N. ${ }^{3}$ \\ ${ }^{1}$ National Authority for Remote Sensing and Space Sciences (NARSS), Cairo, Egypt \\ ${ }^{2}$ Soil and Water Use Department, Agricultural and Biological Research Division, National Research Centre, Cairo 12622, Egyp \\ ${ }^{3}$ Soil Science Department, Faculty of Agriculture, Zagazig University, Zagazig, Egypt.
}

\begin{abstract}
The sustainable agricultural development in the northwest coast of Egypt suffers constantly from the effects of surface runoff. Moreover, there is an urgent need by decision makers to know the effects of runoff. So the aim of this work is to integrate remote sensing and field data and the natural resource conservation service curve number model (NRCS-CN).using geographic information systems (GIS) for spatial evaluation of surface runoff . $\mathrm{CN}$ approach to assessment the effect of patio-temporal variations of different soil types as well as potential climate change impact on surface runoff. DEM was used to describe the effects of slope variables on water retention and surface runoff volumes. In addition the results reflects that the magnitude of surface runoff is associated with $\mathrm{CN}$ values using NRCS-CN model . The average of water retention ranging between 2.5 to $3.9 \mathrm{~m}$ the results illustrated that the highest value of runoff is distinguished around the urban area and its surrounding where it ranged between $138-199 \mathrm{~mm}$. The results show an increase in the amount of surface runoff to $199 \mathrm{~mm}$ when rainfall increases $200 \mathrm{~mm} /$ year. The north of the area may be exposed to erosion hazards more than the south and a change in the soil quality may occur in addition to the environmental imbalance in the region.
\end{abstract}

\section{Introduction}

Sustainable agricultural development in arid and semiarid areas requires water to enable the establishment of agricultural projects that provide food for the population. In Egypt, the water issue is considered one of the topics that conquer the attention of the Egyptian government due to the population increase in terms of food scarcity in addition to regional challenges with the Nile Basin countries. Therefore, by 2020 is expected about 20 percent will be consuming more than it has in Egypt. Water scarcity in Egypt could endanger the country and create instability [1-3] Estimating the volume of runoff in the northern regions of Egypt is considered one of the important things to explain how to take advantage of the lost water that causes many environmental hazards such as soil degradation, desertification and many environmental hazards [4-9].Surrounding factors such as terrain and climate are influence the rate of soil erosion, as the precipitation rate is the main factor determining the volume of runoff and the excess water moves from the surface towards the natural slope. Moreover, the runoff flow rate depends on several factors such as rainfall intensity, soil texture, infiltration rate, organic matter contents, vegetation cover, slope and aspect [1012]. The soil water retention potential $(\mathrm{S})$ and curve number model considers affecting surface runoff [13]. The amount of surface runoff is affected by the ground cover since increasing the vegetative ground cover reduces the erosion of the surface layer and vice versa [14]. Land use and land cover are considered important factors that reduce runoff as field crops, trees and shrubs in addition to forests affect the magnitude and direction of runoff and water storage capacity [15]. During the past three decades, satellite imagery and remote sensing provided data on natural features, and this was reflected in the accuracy of calculating surface runoff and potential floods. GIS has helped modeling surface runoff of ecological importance based on spatial hydrological modeling [16, 17]. Satellite data can contribute to building the number curve taking into account the type of land use /land cover and hydrologic soil groups based on SCS CN where, GIS is used as an efficient tool for preparation input date required by SCS CN model for for increasing water use efficiency to determine the suitable management of arid and semi-arid ecosystems and to support the maximized of returning water benefits in such conditions [18-20]. Several studies have been used Soil Conservation Service Curve Number (SCS CN) and the Potential Maximum Soil Water Retention (PMSWR) based on HSGs, the use of land and land cover as well as topographic factors such as slope and direction of inclination can be taken into account in estimating runoff. $[21,22]$. despite $\mathrm{CN}$ model was Initially established to assess runoff in small agricultural farms and basins, however, it was then used on large areas and in different land uses where, the study area is threatening by several factor such population growth is the most significant

*Corresponding author: salama55@mail.ru 
factor effecting urban sprawl of the current study is to integrate remote sensing data, soil and GIS using hydrological model to estimate surface runoff in the area located between Sidi Barrani and Sallum area

\section{Material and methods}

\subsection{Location characteristics}

The study area lies between longitude $\left(25^{\circ} 8^{\prime} 55^{\prime \prime}\right.$ to $26^{\circ}$ $\left.51^{\prime} 36^{\prime \prime}\right)$ and Latitude $\left(31^{\circ} 46^{\prime \prime}\right.$ to $\left.31^{\circ} 39^{\prime} 40^{\prime \prime}\right)$, in the area between sidi barrani and Sallum area as shown in Figure 1. The catchment area is 766685.98 ha and has a maximum altitude of $250 \mathrm{~m}$ above sea level (asl). The climate of the study area is considered as a part of the Mediterranean region and their rainfall is a seasonally and characterized by fluctuations of the minimum and maximum daily temperatures. However rainfall in February 2020 recorded about $135 \mathrm{~mm}$ according to weather underground website (http://www.wunderground.com/history ) these values are high comparing with the same time . Mean and maximum temperature in February 2020 was 18.51 and $22.78{ }^{\circ} \mathrm{C}$. Satellite image that cover the study area was using Landsat 8 with spatial resolution $30 \mathrm{~m}$ acquired in November 2020. Digital elevation model (DEM) with 30 $\times 30 \mathrm{~m}$ resolution was derived using Shuttle Radar Topography Mission (SRTM) and elevation points were recorded during the field survey by GPS.

\subsection{Land use}

Satellite image (Sentinel-2) acquired in November 2019 was used to produce Land use/land cover of the investigated area. Support vector machine (SVM) was used for this purpose. SVM method is considered as a good method for delineation land use land cover types [23-29] in which taken neighboring pixels in consecration for characterizing the classes of agriculture, bare soil, water, and urban land-use.

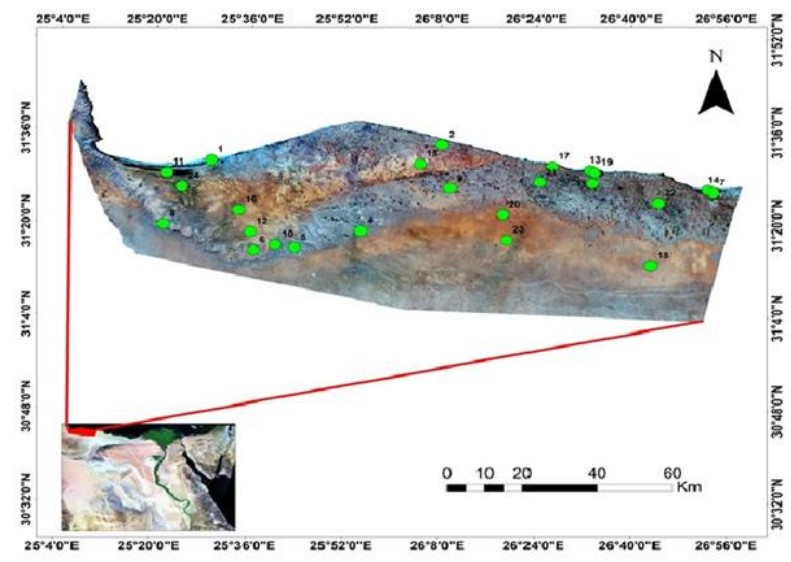

Fig. 1. Location of the study area

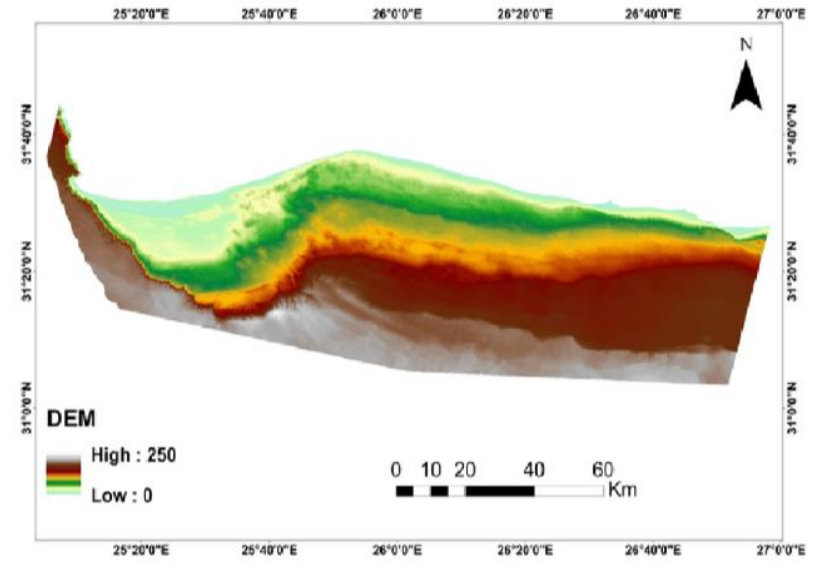

Fig. 2. Digital elevation model

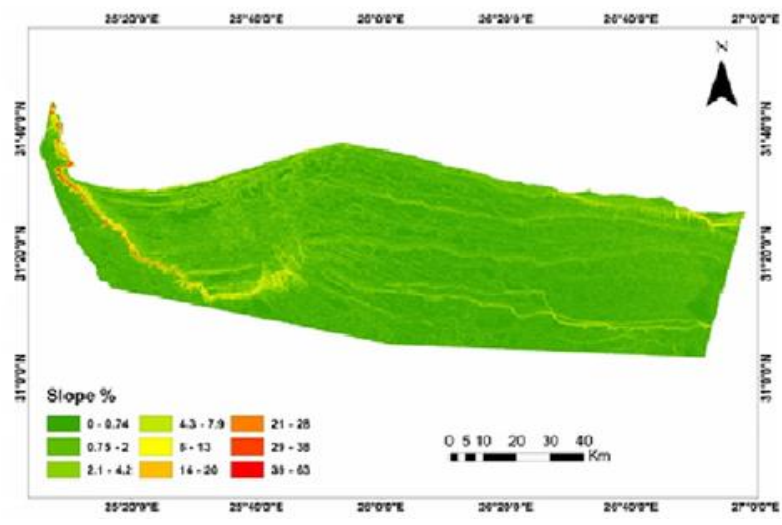

Fig. 3. Slope distribution at the catchment area.

\subsection{Watershed delineation and soil sampling}

Watershed area was delineated using GIS techniques and the network of stream and sub-catchments that contribute to a single stream based on DEM. The elevation ranged from 0 to $250 \mathrm{~m}$ figure 2 . In addition, the slope ranging between 0 to $4.3 \%$ figure 3 . 24 soil profile sites were identified by computing hydrologic soil groups (HSG), soil type, and land-use for the region and combining them to hydrologic response units using GIS. Soil physical analyses were investigated according to [22]. The dominant soil types are sandy loam, loamy sand, loam and sand clay loam soil. Soil field capacity varied from 20 to $45.8 \%$, while dry bulk density varied from 1.5 to $1.75 \mathrm{~g} \mathrm{~cm}-3$.

\subsection{Estimation of Surface runoff}

Quantitative evaluation of surface runoff by applying SCS-CN model using the equation of universal water balance:

$P=Q+E+\Delta S$

Where $P$ : precipitation, $Q$ : runoff, $E$ : evapotranspiration, $\Delta S$ : storage term. Natural resource 
conservation service modified the water balance to the following equation:

$Q=P(F / S)$

Where $F$ : actual loss, $S$ : potential loss. Evaporation of universal water balance equation and storage term has been included into the relation of actual $(F)$ and water potential loss $(S)$. By substituting $F$ (actual loss):

$$
F=P-Q
$$

runoff was formulated as:

$Q=P^{2} /(P+S)$

Equation 4 explains runoff as a function of precipitation and water potential loss $(S)$ that is identified as retention potential or maximum amount of water that is held by the soil. Since runoff is produced if there is rainfall, the term initial abstraction $\left(I_{a}\right)$ has been introduced [14], that is subtracted from the total rainfall to retrieve effective precipitation:

$P_{e}=P-I_{a}$

Where: $P_{e}$ : effective precipitation, $I_{a}$ : initial abstraction. $I_{a}$ is all losses before runoff begins that includes water retained in surface depressions, water abstracted by vegetation, evaporation, and infiltration. NRCS-CN approach is expressed as:

$\mathrm{Q}=(\mathrm{P}-0.2 \mathrm{~S})^{2} /(\mathrm{P}+0.8 \mathrm{~S})$ for $\mathrm{P}>\mathrm{Ia}$

$\mathrm{Q}=0$ for $\mathrm{P} \leq \mathrm{Ia}$;

The relation of the potential water retention $S$ to the curve number is shown in the following equations:

$\mathrm{S}=(25400 / \mathrm{CN})-254$

Conceptually, $\mathrm{CN}$ can vary from 0 to 100 , that is corresponding to $S=\infty$ and $S=0$ respectively.

$\mathrm{Q}=\frac{(P-0.2 S)^{2}}{(P+0.8 S)} \quad \mathrm{P} \geq 0.2 S$,

$\mathrm{Q}=0$ otherwise

Where:

Q: surface runoff $[\mathrm{mm}]$

P: precipitation [mm]

$\mathrm{S}$ : potential water retention $[\mathrm{mm}]$

The computed monthly summarized direct runoff was, taking into account that the precipitation is equal or higher than $0.2 \mathrm{~S}[14]$

\subsection{Spatial distribution mapping}

The runoff mapping was done using Inverse distance weighting (IDW) [30]. It is considered one of the most effective methods in separating urban areas, agricultural areas, using satellite image. This method has depends the calculation of intermediate values based on the nearby known points. According to this method the adjacent points have more weights than distant points and vice versa)

\section{Results and discussion}

\subsection{Surface runoff}

Quantitative evaluation of surface runoff by integration SCS-CN model, remote sensing, soil data using GIS. The land use /land cover greatly affects the increasing the ability of the soil to reduce filtration and the preservation of soil water in the surface layer as it leads to increased water retention in surface soil and effected in the distribution of soil pores [18].

The results of mapping Land use land cover showed that agriculture land occupies an area about $1.5 \%$ of the total area Where agriculture is limited to coastal areas and valleys that depend on water harvesting by traditional methods that can be used for field crops that do not require a large amount of irrigation. Therefore, the agricultural practices in the study area is small compared to the areas where agriculture depends on groundwater and Nile delta areas., urban areas occupies an area $1.3 \%$ and bare soil occupies about 95.5 of the total area as shown in table (1) and figure (4). The northwest coast of Egypt suffers from a lack of agricultural development due to the lack of agricultural projects that depend on monsoon rains during the winter months.

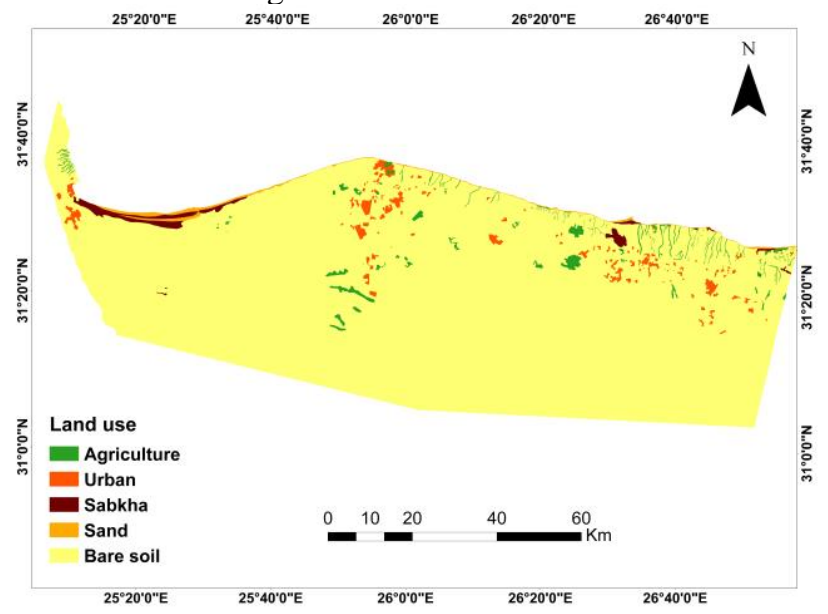

Fig. 4. Land use land cover of the study area

The soil of watershed area varying between sandy loam, loamy sand, loam and sand clay loam soil. Saturated hydraulic conductivity is varying from 5 to 55 cm.d-1. Soil field capacity varied from 20 to $45.8 \%$, while dry bulk density varied from 1.5 to $1.75 \mathrm{~g} \mathrm{~cm}^{-3}$. Organic matter contents vary from 0.14 to $0.8 \%$

The soil of watershed area varying between sandy loam, loamy sand, loam and sand clay loam soil. Saturated hydraulic conductivity is varying from 5 to 55 
cm.d-1. Soil field capacity varied from 20 to $45.8 \%$, while dry bulk density varied from 1.5 to $1.75 \mathrm{~g} \mathrm{~cm}^{-3}$. Organic matter contents vary from 0.14 to $0.8 \%$.

Table 1. Land use land cover of the study area

\begin{tabular}{|c|c|c|}
\hline LULC & Area/_hect. & Area \% \\
\hline Agriculture & 10045 & 1.55 \\
\hline Bare soil & 731792.5 & 95.5 \\
\hline Sabkha & 7257.7 & 0.95 \\
\hline Sand & 5939.9 & 0.7 \\
\hline Urban & 11649.42 & 1.3 \\
\hline total & 766685.6 & 100 \\
\hline
\end{tabular}

The weeds, and organic materials in the surface layers contribute to increasing the ability of the soil to retain water on the one hand in increasing the aggregation of soil consistency on the other hand It also helps in providing the natural plant with the appropriate nutrients. It also helps in increasing the soil aggregation and improving its physical and chemical properties. Thus, it makes the soil more resistant to water erosion. The area is characterized by almost flat to sloping as, the northern parts have slope values ranging between 1- $4.2 \%$. In addition, the southern part has slope gradient ranging reached to $63 \%$ as shown in figure 3. Furthermore, HSG was calculating soil parameters and land use (Table 1) where the results revel that $\mathrm{C}$ group is the dominant in the study area. Meanwhile group D occupy the smallest areas. Spatial distributions (S) are mainly determined using LULC and soil types of the areas Figure 5. The results of using SCS model based on the next parameters, slope, aspect, soil texture, infiltration, rate and soil water retention. Figure 6 illustrated the spatial distribution of $\mathrm{CN}$ values for the study area as they ranging between 60 to 96. Spatial distribution of water retention of the study area varies between 0 to 6.7. the most of the area have average of water retention ranging between 2.5 to $3.9 \mathrm{~mm}$ Figure 7. The runoff in February 2020 where the rainfall amount reached around $140 \mathrm{~mm}$ these values is high comparing with the same time year the results showed that runoff value ranges between 133 to $139 \mathrm{~mm}$ Figure 8 . The maximum values were recognized at the slope area and foot slops. Runoff values ranging between 136-139 in the area located at south of study area where slope tends to generate more runoff than do lowland areas. On the other hand an about $7 \%$ of the total study area that characterized by lowest values of runoff ranging between 133 to 135 as the soil texture vary between sand clay loam to loamy sand. The results show that the areas with the highest slope are more exposed to the risk of corrosion than other flat areas. We notice that in the valley areas that have a large slope receive large amounts of erosion and may change the properties and quality of the soil where the salts are concentrated in the north of the region and may create various environmental hazards.
[31-33]. Figure 9 shows that when the rainfall rate increases to $200 \mathrm{~mm}$ and this rate is happen frequently, it was notice an increase in the amount of surface runoff to $199 \mathrm{~mm}$ comparing with 139 at rainfall $140 \mathrm{~mm} /$ year. This means that the amount of annual rain is the factor affecting the amount of surface runoff in the absence of factors that reduce runoff, such as the rare of ground cover and suitable management. On the other hand It has been observed that the north of the region has been affected mare than the south as the slope helped increase the risk along with the soft texture of the soil, which can be removed and moved in the absence of a natural plant that reduces erosion. The phenomenon of runoff has many effects on environmental equilibrium, not only on the change of soil properties, but also on surface water, and it has also affected the up growth of species of natural plants. In addition, it may cause environmental pollution as a result of transport the heavy elements from one place and concentrating them in another place [3438].

\section{Conclusion}

The Surface runoff in the north west coast is considered a hazard phenomenon that threat the agricultural development. Surface runoff is associated with many factors such as soil moisture and topographic parameter such slope and aspect beside land-use, influences rate, water holding capacity, is affected by soil characteristics such as texture, soil organic matter. Remote sensing images consider as helpful and essential tools for estimation and monitoring the environmental phenomena and supply with essential information about the type of land use. Thus, the integration of remote sensing data and soil properties using the NRCS-CN model. This study highlights the magnitude of spatial distribution of surface runoff in Sidi Barrani and Sallum. Finally, the results obtained show the spatial distribution of the amount of surface runoff, so it is necessary to devise suitable solutions to mitigate the effects of the severity of runoff. The necessity of developing water harvesting methods and raising the efficiency of storing water from surface runoff for its potential use in sustainable agricultural development.

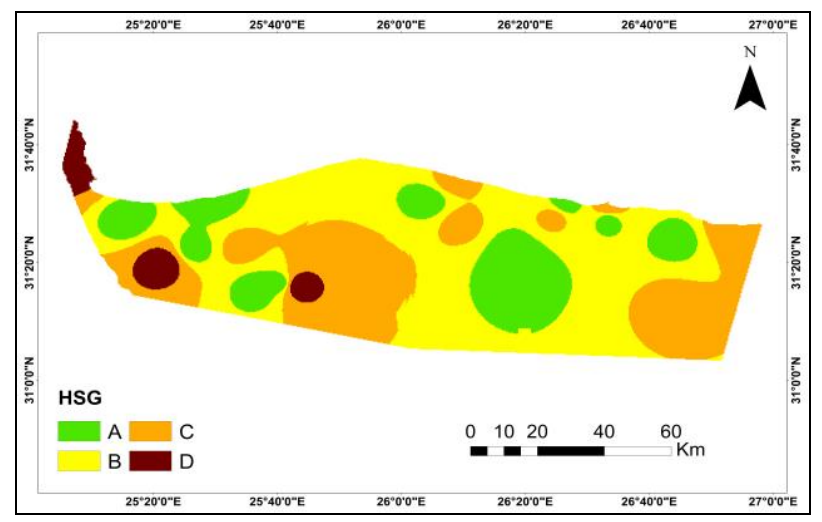

Fig. 5. Spatial distribution of HSG 


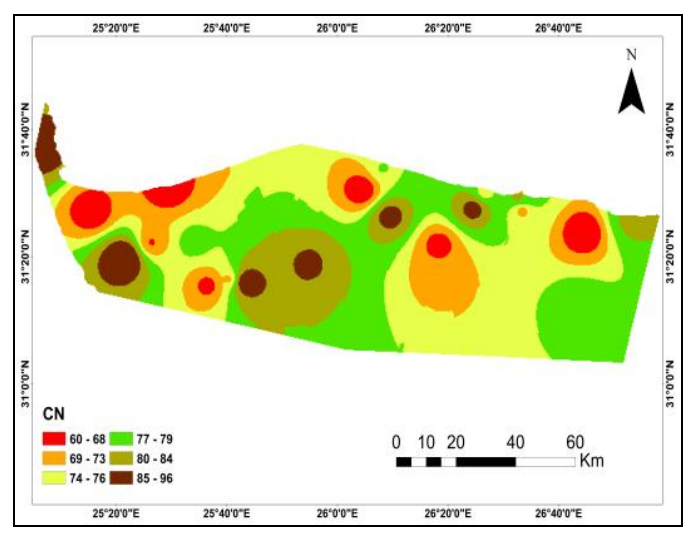

Fig. 6. Spatial distribution curve number values

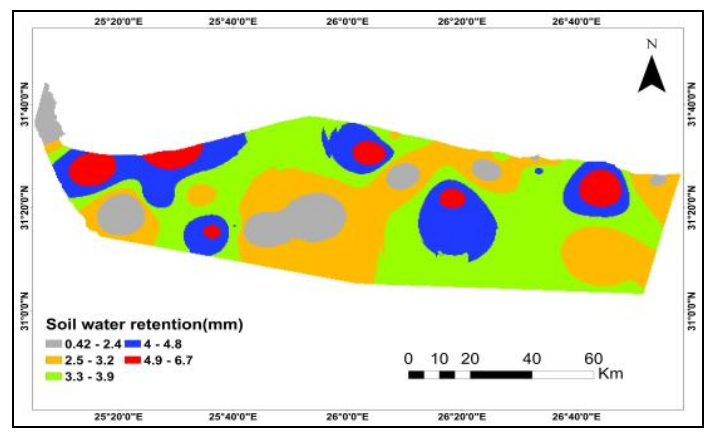

Fig. 7. Spatial distribution of water retention

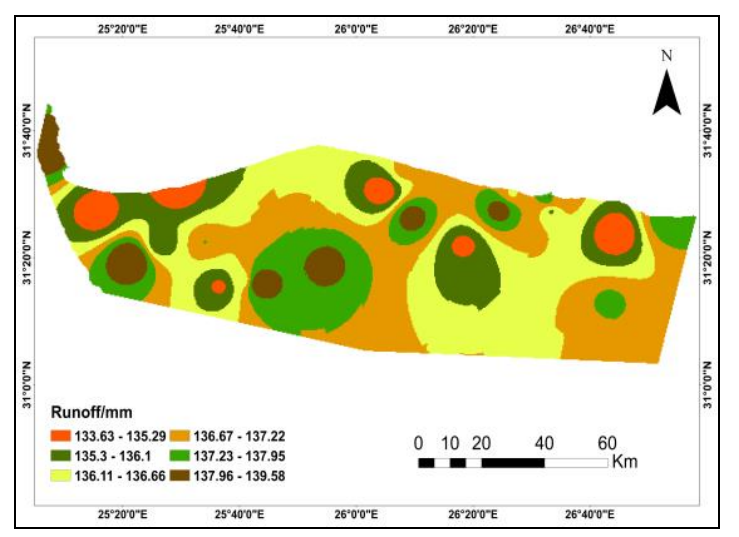

Fig. 8. Spatial distribution for Runoff at a rainfall rate of 140 $\mathrm{mm} /$ year

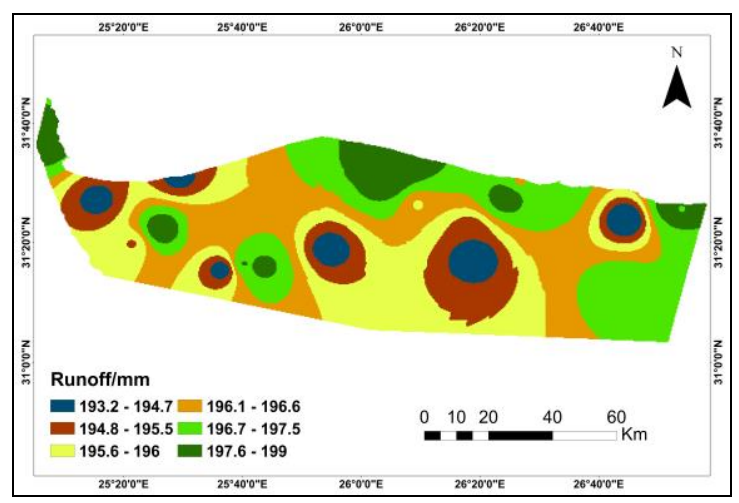

Fig. 9. Spatial distribution for Runoff

\section{References}

1. Ministry of Water Resources and Irrigation, Egypt (MWRIE). Water Scarcity in Egypt. report 1-5., (2014).

http://www.mfa.gov.eg/SiteCollectionDocuments/Eg ypt\%20Water\%20Resources\%20Paper_2014.pdf.

2. Mohamed, E. S., Belal, A. A., \& Abu-hashim, M.. Quantitative assessment of surface runoff at arid region: a case study in the Middle of Nile Delta. Bulletin of the National Research Centre, 43(1), 186 (2019).

3. Mohamed, E. S., Saleh, A. M., \& Belal, A. A.. Sustainability indicators for agricultural land use based on GIS spatial modeling in North of SinaiEgypt. The Egyptian Journal of Remote Sensing and Space Science, 17(1), 1-15 (2014).

4. Mohamed, E. S., Belal, A., \& Saleh, A.. Assessment of land degradation east of the Nile Delta, Egypt using remote sensing and GIS techniques. Arabian Journal of Geosciences, 6(8), 2843-2853 (2013).

5. Abd-Elmabod, S. K., Mansour, H., Hussein, A. A. E. F., Mohamed, E. S., Zhang, Z., Anaya-Romero, M., ... \& Jordán, A.. Influence of irrigation water quantity on the land capability classification. Plant Archives, 19(2), 2253-2261(2019).

6. Mohamed, E. S.. Spatial assessment of desertification in north Sinai using modified MEDLAUS model. Arabian Journal of Geosciences, 6(12), 4647-4659,(2013).

7. Hammam, A. A., \& Mohamed, E. S.. Mapping soil salinity in the East Nile Delta using several methodological approaches of salinity assessment. The Egyptian Journal of Remote Sensing and Space Science,(2018).

8. Muñoz-Rojas, M., Jordán, A., Zavala, L. M., De la Rosa, D., Abd-Elmabod, S. K., \& Anaya-Romero, M.. Impact of land use and land cover changes on organic carbon stocks in Mediterranean soils (19562007). Land Degradation \& Development, 26(2), 168-179,(2015).

9. Mohamed, E. S., Schütt, B., \& Belal, A. Assessment of environmental hazards in the north western coastEgypt using RS and GIS. The Egyptian Journal of Remote Sensing and Space Science, 16(2), 219. 229,(2013).

10. Michel, Claude, Vazken Andréassian, and Charles Perrin. "Soil conservation service curve number method: How to mend a wrong soil moisture accounting procedure?." Water Resources Research 41, no. 2 (2005).

11. Morgan, R. P. C. "A simple approach to soil loss prediction: a revised Morgan-Morgan-Finney model." Catena 44, no. 4 (2001): 305-322 Dunne T. and L. B. Leopold, 1978. Water in Environmental Planning, W. H. Freeman Co., San Francisco, 818 pp.

12. Hawkins, Richard H. "Asymptotic determination of runoff curve numbers from data." Journal of 
Irrigation and Drainage Engineering 119, no. 2 (1993): 334-345..

13. Elhakeem, Mohamed, and Athanasios N. Papanicolaou. "Estimation of the runoff curve number via direct rainfall simulator measurements in the state of Iowa, USA." Water Resources Management 23, no. 12 (2009): 2455-2473..

14. Mishra, Surendra Kumar, and Vijay P. Singh. "Another look at SCS-CN method." Journal of Hydrologic Engineering 4, no. 3 (1999): 257-264..

15. Hendawy, Ehab, A. A. Belal, E. S. Mohamed, Abdelaziz Elfadaly, Beniamino Murgante, Ali A. Aldosari, and Rosa Lasaponara. "The prediction and assessment of the impacts of soil sealing on agricultural land in the North Nile Delta (Egypt) using satellite data and GIS modeling." Sustainability 11, no. 17 (2019): 4662.

16. Mohamed, E. S., Abu-hashim, M., AbdelRahman, M. A., Schütt, B., \& Lasaponara, R. Evaluating the effects of human activity over the last decades on the soil organic carbon pool using satellite imagery and GIS techniques in the Nile Delta Area, Egypt. Sustainability, 11(9), (2019); 2644.

17. Abu-Hashim, Mohamed, Elsayed Mohamed, and Abd-ElAziz Belal. "Identification of potential soil water retention using hydric numerical model at arid regions by land-use changes." International Soil and Water Conservation Research 3, no. 4 (2015): $305-$ 315.

18. Soulis, K. X., J. D. Valiantzas, N. Dercas, and P. A. Londra. "Analysis of the runoff generation mechanism for the investigation of the SCS-CN method applicability to a partial area experimental watershed." Hydrology \& Earth System Sciences Discussions 6, no. 1 (2009).

19. Latha M., M.Rajendran, A.Murugappan .Comparison of GIS based SCS-CN and Strange table Method of Rainfall-Runoff Models for Veeranam Tank, Tamil Nadu, India. International Journal of Scientific \& Engineering Research, Volume 3, Issue 10, October2012 ; 1 ISSN 2229-5518

20. Mantey S. and Naa Dedei Tagoe. Spatial Modelling of Soil Conservation Service Curve Number Grid and Potential Maximum Soil Water Retention to Delineate Flood Prone Areas: A Case Study . Research Journal of Environmental and Earth Sciences 5(8): 449-456,(2013).

21. Klute, A.. Water retention: Laboratory methods. In: Klute, A. (Ed). Methods of soil analysis. Part 1. 2nd edition. Agronomy Monograph 9, pp 635-662. ASA and SSSA, Madison, WI.. Physics and Chemistry of the Earth, 28, 1377-1387,(1986).

22. Abu-Hashim, Mohamed, Elsayed Mohamed, and Abd-ElAziz Belal. "Identification of potential soil water retention using hydric numerical model at arid regions by land-use changes." International Soil and Water Conservation Research 3, no. 4 (2015): $305-$ 315 .
23. Elbeih S. F. and El-Zeiny A. M.. Qualitative assessment of groundwater quality based on land use spectral retrieved indices: Case study Sohag Governorate, Egypt. Remote Sensing Applications: Society and Environment; 10: (2018);82-92. https://doi.org/10.1016/j.rsase.2018.03.001

24. El-Zeiny, Ahmed M., and Hala A. Effat. "Environmental analysis of soil characteristics in ElFayoum Governorate using geomatics approach." Environmental monitoring and assessment 191, no. 7 (2019): 463

25. El-Alfy, Muhammad A., Amany F. Hasballah, Hazem T. Abd El-Hamid, and Ahmed M. El-Zeiny. "Toxicity assessment of heavy metals and organochlorine pesticides in freshwater and marine environments, Rosetta area, Egypt using multiple approaches." Sustainable Environment Research 29, no. 1 (2019): 19.

26. El-Zeiny, Ahmed M., Sameh B. El Kafrawy, and Mahmoud H. Ahmed. "Geomatics based approach for assessing Qaroun Lake pollution." The Egyptian Journal of Remote Sensing and Space Science (2019).

27. El-Zeiny, Ahmed M., and Salwa F. Elbeih. "GISBased Evaluation of Groundwater Quality and Suitability in Dakhla Oases, Egypt." Earth Systems and Environment 3, no. 3 (2019): 507-523.

28. Mohamed, E.S.; Saleh, A.M.; Belal, A.B.; Gad, A. Application of near-infrared reflectance for quantitative assessment of soil properties. The Egyptian Journal of Remote Sensing and Space Science, 2018, 21(1), pp.1-14.

29. Burrough and McDonnell, 1998 P.A. Burrough, R.A. McDonnellCreating continuous surfaces from point dataP.A. Burrough, M.F. Goodchild, R.A. McDonnell, P. Switzer, M. Worboys (Eds.), Principles of Geographic Information Systems, Oxford University Press, Oxford, UK (1998).

30. AbdelRahman, Mohamed AE, A. Shalaby, and E. S. Mohamed. "Comparison of two soil quality indices using two methods based on geographic information system." The Egyptian Journal of Remote Sensing and Space Science 22, no. 2 (2019): 127-136.

31. Mohamed, E. S., Abdelraouf Ali, Mohammed ElShirbeny, Khaled Abutaleb, and Sameh M. Shaddad. "Mapping soil moisture and their correlation with crop pattern using remotely sensed data in arid region." The Egyptian Journal of Remote Sensing and Space Science (2019).

32. El Nahry, A. H., and E. S. Mohamed. "Potentiality of land and water resources in African Sahara: a case study of south Egypt." Environmental Earth Sciences 63, no. 6 (2011): 1263-1275.

33. El-Magd, Islam Abou, and Ahmed El-Zeiny. "Quantitative hyperspectral analysis for characterization of the coastal water from Damietta to Port Said, Egypt." The Egyptian Journal of Remote Sensing and Space Science 17, no. 1 (2014): 61-76. 
34. Amato, Filippo, Josef Havel, Abd-Alla Gad, and Ahmed Mohamed El-Zeiny. "Remotely sensed soil data analysis using artificial neural networks: a case study of El-Fayoum depression, Egypt." ISPRS International Journal of Geo-Information 4, no. 2 (2015): 677-696.

35. El-Zeiny, Ahmed, and Sameh El-Kafrawy. "Assessment of water pollution induced by human activities in Burullus Lake using Landsat 8 operational land imager and GIS." The Egyptian journal of remote sensing and space science 20 (2017): S49-S56.

36. El-Zeiny, Ahmed, Asmaa El-Hefni, and Mohamed Sowilem. "Geospatial techniques for environmental modeling of mosquito breeding habitats at Suez
Canal Zone, Egypt." The Egyptian Journal of Remote Sensing and Space Science 20, no. 2 (2017): 283-293.

37. El-Zeiny, Ahmed M., and Hala A. Effat. "Environmental monitoring of spatiotemporal change in land use/land cover and its impact on land surface temperature in El-Fayoum governorate, Egypt." Remote sensing applications: society and environment 8 (2017): 266-277.

38. El-Shirbeny, Mohammed A., E. S. Mohamed, and Abdelazim Negm. "Estimation of Crops Water Consumptions Using Remote Sensing with Case Studies from Egypt." In Conventional Water Resources and Agriculture in Egypt, pp. 451-469. Springer, Cham, 2018. 